JURNAL MANAJEMEN VOL. 4 NO. 1 JUNI 2014

\title{
KEMITRAAN BUMN DENGAN UKM SEKTOR INDUSTRI \\ DI KABUPATEN SLEMAN: \\ ANALISIS MODEL BALANCE SCORECARD
}

\author{
Gendro Wiyono \\ Magister Manajemen UST \\ gw1@doctor.com
}

\begin{abstract}
The research was conducted to determine the effect on the performance of SOEs Partnership Program SMEs in Sleman, Yogyakarta Special Region, using the balance scorecard approach to performance evaluation. In assessing the implementation of the coaching process, researchers use a measure of the principles of the new paradigm of Osborne and Gaebler (Tamba, 2004), while to know the direction of marketing strategies using the concept of Kotler and Armstrong (1989). The results showed that the implementation is not in accordance with the spirit of partnership that mandated by the rules. Working Capital Loans are given relatively small, and Investment Assistance Loans are only given to 10 SMEs $(27.78 \%)$. Fostering human resources in the form of education and apprenticeship is never done, while the training is only carried out on eight SME $(22.22 \%)$. In addition, the Marketing and Promotion Development aid is only granted to 12 SMEs (33.33\%). The value of loans granted though relatively small, but was still significant $(0.675 ;$ t-stat $=2.069)$ on shareholder value, this is because the loans are disbursed only to micro-businesses that had little effect so the increase that occurred has no positive value for welfare of society at large. Coaching HR does not provide a significant positive effect, even a negative effect on organizational capital (-0.465; t-stat=6.658) and no effect also on human capital (0.000). Similarly, the Business Development also no significant effect on shareholder value (-0.435; $t$-stat $=1.145)$ but significant positive effect on human capital (0.877; t-stat=17.417). Furthermore, the findings based on the principles of the new paradigm suggests that the implementation of the coaching was done SOE Partners Equity Loans weakened the influence of shareholder value $(0.241 ; t$-stat=1.498), whereas the implementation of the Referral Marketing Strategy Business Development to strengthen the influence of shareholder value (0.781; t-stat=4.252). Finally it can be concluded that the Capital Loan significant positive effect on shareholder value but does not give effect to the wider community. Positive and significant influence of human capital to organizational capital and equity firms occurred not due to the results of state-owned development partners, but tend to be because SMEs itself in terms of relationship and managerial capabilities.
\end{abstract}

\section{A. LATARR BETHAKANGGnomi Indonesia} yang berulang kali terjadi antara lain disebabkan rapuhnya pondasi ekonomi Indonesia. Sistem konglomerasi dalam

pembangunan ekonomi telah mengesampingkan potensi ekonomi kecil. Ketika krisis melanda negeri ini kesadaran baru muncul bahwa bisnis yang dibangun dengan sistem konglomerasi banyak yang ambruk. Konsep ekonomi kerakyatan menjadi solusi alternatif sebagai konsep ekonomi yang berbasis pada usaha kecil menengah. Ekonomi kerakyatan diharapkan dapat menjadi sistem yang handal untuk mengurangi pengangguran, mengurangi jumlah penduduk miskin, meningkatkan pertumbuhan ekonomi yang akhirnya akan meningkatkan kesejahteraan rakyat.

Namun demikian peran besar UMKM adalah sebuah ironi. Digambarkan oleh Anoraga dan Sudantoko (2002:225-6) bahwa UMKM 
banyak kelemahannya seperti: sistem pembukuan tidak mengikuti kaidah pembukuan standar; marjin usaha tipis; modal terbatas; pengalaman manajerial terbatas; skala ekonomi kecil; dan kemampuan pemasaran terbatas. Melihat kenyataan ini, maka pemerintah melalui BUMN melaksanakan Program Kemitraan BUMN dengan tujuan untuk meningkatkan kemampuan usaha kecil agar menjadi tangguh dan mandiri yang didukung dengan memanfaatkan dana dari bagian laba BUMN. Keinginan pemerintah sudah begitu mantab, akan tetapi tidak dapat dipungkiri masih banyak sederetan hasil tidak seperti yang diharapkan. Kebijakan pemerintah melalui pendekatan pinjaman bergulir baik melalui departemen maupun BUMN selama ini lebih sering berakhir dengan banyaknya kredit macet. Pola pembiayaan yang diharapkan mampu memunculkan efek bola salju (snowball effect) kenyataannya justru melahirkan efek kembang gula (candy effect), yang menyusut dari waktu ke waktu hingga akhirnya habis. Nampaknya aspek permodalan bukanlah satu-satunya kendala yang dihadapi UMKM.

Seberapa besar keberhasilan Program Kemitraan BUMN ini dalam upaya membantu meningkatkan kemampuan usaha kecil di Kabupaten Sleman Provinsi Daerah Istimewa Yogyakarta, tentu menjadi sebuah pertanyaan yang perlu mendapatkan jawaban. Untuk itulah maka penelitian ini dilakukan untuk dapat mengetahui keberhasilan seperti apa yang dapat diraih. Sektor industri dijadikan pilihan penelitian mengingat sektor tersebut berperan penting dalam kontribusi pembangunan nasional dari tahun ke tahun. Penelitian ini dilakukan dengan pendekatan Balanced Scorecard, yang memperlihatkan perluasan ukuran kinerja tidak hanya terpusat pada perspektif keuangan tetapi juga perspektif non-keuangan yang meliputi perpektif pelanggan, proses bisnis, serta pembelajaran dan pertumbuhan. Balanced Scorecard akan dapat menunjukkan seberapa jauh program kemitraan BUMN menghasilkan sasaran-sasaran strategik yang akhirnya menjadi penyebab utama dihasilkannya kinerja keuangan. Ukuran kinerja dengan menggunakan perspektif tersebut diatas akan dapat dilakukan pengukuran pada sasaran strategik yang diinginkan seperti terlihat pada gambar dibawah ini.

Tabel 1: Perspektif dan Sasaran Strategik

\begin{tabular}{|l|l|}
\hline PERSPEKTIF & SASARAN STRATEGIK \\
\hline KEUANGAN & Shareholder Value \\
\hline PELANGGAN & Firm Equity \\
\hline PROSES BISNIS & Organizational Capital \\
\hline $\begin{array}{l}\text { PEMBELAJARAN } \\
\text { \& } \\
\text { PERTUMBUHAN }\end{array}$ & Human Capital \\
\hline
\end{tabular}

Sumber: Mulyadi (2001)

Pengukuran kinerja berbasis
balanced scorecard, memiliki
keunggulan: (1) komprehensif, (2)
koheren, (3) seimbang, dan (4) terukur.
Tiap-tiap unsur dalam dinamika
organisasi saling berkaitan antara yang satu dengan lainnya untuk mencapai sasaran perusahaan yang diinginkan. Tercapainya potensi perspektif nonkeuangan sebenarnya menjadi pemicu bagi tercapainya perspektif keuangan yang menjadi sasaran. Pengukuran 
berbasis balance scorecard diharapkan dapat memetakan secara menyeluruh berbagai aspek yang mengindikasikan apakah program kemitraan BUMN telah berhasil ataukah tidak dalam upaya mendorong perkembangan usaha kecil sektor industri di Kabupaten Sleman. Namun demikian perlu disadari bahwa keberhasilan pembinaan yang dilakukan tidak lepas dari cara-cara atau model yang diterapkan pada pembinaan tersebut. Model pembinaan yang bagus tentunya lebih menjamin keberhasilan UMKM sebagai mitra binaan dibandingkan model pembinaan yang tidak bagus.

Permasalahan yang dihadapi UMKM kedepan akan lebih menonjol disebabkan oleh faktor-faktor eksternal. Permasalahan akibat tuntutan lingkungan pasar yang semakin kompleks tidak akan mungkin dapat diatasi oleh pelaku UMKM itu sendiri. Padahal begitu besar harapan terhadap UMKM untuk menjadi mesin pertumbuhan ekonomi dan alat pemerataan pendapatan. Dalam mereduksi permasalahan eksternal UMKM inilah peran pemerintah sangat didambakan. Agar peran pemerintah melalui kiprah BUMN dapat terlaksana, tentunya membutuhkan prinsip-prinsip paradigma baru yang dapat menghasilkan kualitas barang dan jasa yang memiliki nilai tinggi (high quality public goods and services). Terkait dengan masalah tersebut, sudah barang tentu tidak lepas dari kemampuan menerapkan strategi pemasaran yang tepat sehingga barang dan jasa dapat bersaing dan terjual demi kelangsungan UMKM itu sendiri.

Berdasarkan latar belakang diatas, maka masalah penelitian yang dirumuskan adalah: "Apakah Program Kemitraan BUMN dalam bentuk pemberian pinjaman maupun pembinaan berpengaruh positip terhadap peningkatan UMKM di kabupaten
Sleman menggunakan pendekatan Balanced Scorecard". Dengan mengetahui hasil penelitian ini, diharapkan akan memberikan manfaat: (1) secara teoritis diharapkan menjadi sumber referensi bagi pengembangan teori dan penelitian selanjutnya di bidang UMKM; (2) secara praktis diharapkan dapat digunakan sebagai referensi bagi penyempurnaan program kemitraan BUMN; dan (3) dapat digunakan sebagai referensi bagi kebijakan pemerintah dibidang pembinaan dan pengembangan UMKM.

\section{B KAJIAN PUSTAKA}

1. Program Kemitraan BUMN

Program kemitraan

dilaksanakan berdasarkan Peraturan Menteri Negara BUMN No: Per05/MBU/2007 serta dilandasi pula dengan Undang Undang Republik Indonesia Nomor 20 Tahun 2008. Adapun bentuk Program Kemitraan meliputi: (1) pemberian pinjaman modal kerja, (2) pemberian pinjaman aktiva tetap produktif (investasi), (3) program pendampingan dalam rangka capacity building dalam bentuk pendidikan, pelatihan dan pemagangan, dan (4) capacity bulding dibidang produksi, pemasaran dan promosi. Usaha yang dapat dibiayai adalah usaha yang produktif di semua sektor ekonomi (industri, perdagangan, pertanian, perkebunan, perikanan, jasa, lain-lain) dengan ketentuan yang diatur oleh setiap BUMN Pembina sesuai dengan pelimpahan melalui Corporate Action Scheme.

Dalam Undang-Undang

Nomor 20 Tahun 2008 dan Peraturan Menteri BUMN No. Per05/MBU/2007, usaha kecil yang dapat ikut serta dalam program kemitraan adalah sebagai berikut: 
(1) Memilki kekayaan bersih paling banyak Rp. 200 Juta, tidak termasuk tanah dan bangunan tempat usaha, (2) memiliki hasil penjualan tahunan paling banyak Rp 1 milyar, (3) milik Warga Negara Indonesia, (4) berdiri sendiri, bukan anak perusahaan atau cabang dari perusahaan menengah atau besar lain, (5) berbentuk usaha orang perseorangan, badan usaha yang tidak berbadan hukum maupun berbadan hukum termasuk koperasi, (6) mempunyai potensi untuk dikembangkan, (7) telah melakukan kegiatannya minimal 1 tahun, dan (8) belum memenuhi persyaratan perbankan.

Usaha Menengah, Kecil, dan Mikro (UMKM)

Usaha Mikro, Kecil dan Menengah (UMKM) berdasarkan Undang-Undang Nomor 20 Tahun 2008 sebagai berikut:

Tabel 2: Kriteria UMKM

\begin{tabular}{|c|c|c|c|}
\hline \multirow{2}{*}{ No } & \multirow{2}{*}{ Uraian } & \multicolumn{2}{|l|}{ Kriteria } \\
\hline & & Aset & Omset \\
\hline 1 & Usaha Mikro & Maks. 50 Juta & Maks. 300 Juta \\
\hline 2 & Usaha Kecil & $>50$ Juta -500 Juta & $>300$ Juta $-2,5 \mathrm{M}$ \\
\hline 3 & $\begin{array}{l}\text { Usaha } \\
\text { Menengah }\end{array}$ & $>500$ Juta $-10 \mathrm{M}$ & $>2,5 \mathrm{M}-50 \mathrm{M}$ \\
\hline
\end{tabular}

Sumber: Undang-Undang RI Nomor: 20 Tahun 2008

Berangkat dari berbagai masalah, tantangan dan hambatan tersebut diatas, maka dalam pengembangan UMKM, pemerintah telah menetapkan arah kebijakannya sebagai berikut:

a. Usaha kecil dan menengah diarahkan untuk memberikan kontribusi terhadap pertumbuhan ekonomi, penciptaan lapangan kerja, dan peningkatan daya saing; sedangkan skala mikro diarahkan untuk peningkatan pendapatan masyarakat kelompok rendah. b. Memperkuat kelembagaan dengan menerapkan prinsipprinsip tata kepemerintahan yang baik (good governance).

c. Memperluas basis dan kesempatan berusaha serta menumbuhkan wirausaha baru berkeunggulan untuk mendorong pertumbuhan, peningkatan ekspor dan penciptaan lapangan kerja.

d. Mengembangkan UMKM untuk makin berperan sebagai penyedia barang dan jasa pasar domestik yang semakin berdaya saing dengan produk impor, khususnya untuk 


\author{
memenuhi kebutuhan \\ masyarakat banyak. \\ e. Meningkatkan kemandirian \\ gerakan koperasi.
}

\section{Dana Program Kemitraan}

Seperti telah diatur dalam Peraturan Menteri Negara Badan Usaha Milik Negara Nomor Per5/MBU/2007 Pasal 11, Dana Program Kemitraan diberikan dalam bentuk:

a. Pinjaman untuk membiayai modal kerja dan atau pembelian aktiva tetap dalam rangka meningkatkan produksi penjualan.

b. Pinjaman khusus untuk membiayai kebutuhan dana pelaksanaan kegiatan usaha Mitra Binaan yang bersifat pinjaman tambahan dan berjangka pendek dalam rangka memenuhi pesanan dari rekanan usaha Mitra Binaan.

c. Beban Pembinaan, untuk membiayai: (1) pendidikan, pelatihan, pemagangan, pemasaran, promosi, dan halhal lain yang menyangkut peningkatan produktifitas Mitra Binaan serta untuk pengkajian/penelitian yang berkaitan dengan Program Kemitraan; (2) hibah dengan besaran maksimal 20\% (dua puluh persen) dari dana Program Kemitraan yang disalurkan pada tahun berjalan; (3) beban pembinaan ini hanya dapat diberikan kepada atau untuk kepentingan Mitra Binaan.

\section{Pinjaman Modal Kerja}

Setiap perusahaan selalu membutuhkan modal kerja guna membelanjai operasinya sehari-hari, misalkan untuk pembelian bahan baku, membayar gaji dan upah. Dana yang dikeluarkan itu diharapkan akan segera dapat kembali masuk ke dalam perusahaan dalam waktu yang pendek melalui penjualan hasil produksinya. Uang yang masuk dari penjualan hasil produksi itu segera dikeluarkan lagi untuk membiayai operasi selanjutnya, demikian seterusnya. Dengan demikian maka dana tersebut akan terus berputar setiap periodenya selama hidup perusahaan. Menurut Riyanto (2008: p57) pengertian modal kerja dapat dikemukakan adanya beberapa konsep, yaitu: a. konsep kuantitatif, b. konsep kualitatif, dan c. konsep fungsional.

\section{a. Konsep Kuantitatif}

Modal kerja menurut konsep ini adalah keseluruhan dari jumlah aktiva lancar. Modal kerja dalam pengertian ini sering disebut dengan modal kerja bruto (gross working capital).

b. Konsep Kualitatif

Menurut konsep ini, dikaitkan dengan sebagian dari aktiva lancer yang harus disediakan untuk memenuhi kewajiban keuangan yang segera harus dipenuhi, di mana bagian aktiva lancar ini tidak boleh digunakan untuk membiayai operasi perusahaan guna menjaga likuiditasnya. Modal kerja dalam pengertian ini sering disebut dengan modal kerja neto (net working capital).

\section{c. Konsep Fungsional}

Konsep ini mendasarkan pada fungsi dana dalam menghasilkan pendapatan (income). Setiap dana yang digunakan dalam perusahaan dimaksudkan untuk menghasilkan pendapatan. Ada sebagian dana yang digunakan 
dalam periode akunting tertentu yang seluruhnya langsung menghasilkan pendapatan, atau baru menghasilkan pendapatan pada periode berikutnya.

\section{Pinjaman Investasi}

Investasi dalam aktiva tetap seperti halnya investasi pada aktiva lancar juga mengalami proses perputaran. Secara konsepsional sebenarnya tidak ada perbedaan antara investasi dalam aktiva tetap dengan investasi dalam aktiva lancar. Bedanya, perputaran dana yang tertanam pada kedua aktiva itu. Investasi pada aktiva lancar diharapkan akan dapat diterima kembali dalam waktu dekat dan secara sekaligus, sebaliknya investasi pada aktiva tetap baru akan diterima kembali oleh perusahaan selama kurun waktu beberapa tahun dan kembalinya secara berangsur-angsur melalui depresiasi (Riyanto, 2008: p115).

Menurut Brigham \& Houston (2006: p514), perusahaan pada umumnya mengkatagorikan proyekproyeknya (investasinya) sebagai berikut:

a. Penggantian: pemeliharaan bisnis. Adalah investasi untuk mengganti peralatan yang sudah aus atau rusak yang digunakan dalam proses produksi.

b. Penggantian: pengurangan biaya. Adalah investasi untuk mengganti peralatan yang sudah using, untuk menurunkan biaya tenaga kerja, bahan baku, dll.

c. Ekspansi produk atau pasar yang sudah ada. Adalah investasi untuk meningkatkan output, dengan tujuan memperluas jaringan pemasaran. d. Ekspansi ke produk atau pasar yang baru. Adalah investasi untuk menghasilkan produk baru atau memperluas pemasaran daerah geografis yang saat ini belum dilayani.

e. Keselamatan dan Lingkungan Hidup. Adalah investasi yang dilakukan untuk memenuhi ketentuan dari pemerintah, perjanjian dengan serikat pekerja, dll.

\section{Pembinaan Sumber Daya Manusia}

Dana Program Kemitraan dapat dimanfaatkan untuk melakukan pembinaan sumber daya manusia guna peningkatan produktifitas yang meliputi: pendidikan, pelatihan, pemagangan, bantuan pemasaran dan promosi. Semua kegiatan ini dimaksudkan untuk lebih meningkatkan kemampuan sumber daya manusia yang terlibat dalam UMKM yang menjadi mitra binaan BUMN. Kegiatan pembinaan SDM personil ini sangat bermanfaat dalam situasi dimana para personil kekurangan kecakapan dan pengetahuan tentang hal-hal yang berkaitan dengan pekerjaannya. Kegiatan pembinaan ini dimaksudkan agar lebih mengaktifkan kerja para anggota organisasi yang kurang aktif sebelumnya, pengalaman yang terbatas, maupun pengetahuan yang minim.

Menurut Notoatmojo (1992), pendidikan pada umumnya berkaitan dengan mempersiapkan calon tenaga kerja yang diperlukan, sedangkan pelatihan lebih berkaitan dengan peningkatan ketrampilan personil yang sudah bekerja. Selanjutnya apabila dikaji lebih mendalam, maka perbedaan utama dari pendidikan dan pelatihan 
terletak pada beberapa hal, yaitu: Waktu (pelatihan jangka waktunya singkat, sedangkan pendidikan lebih lama), bidang kajian (pelatihan spesifik, pendidikan lebih luas), dan tujuan (pelatihan untuk meningkatkan kinerja/skil tertentu yang langsung diterapkan dalam pekerjaan, sedangkan pendidikan lebih umum dan menyeluruh). Sementara itu pembinaan personil melalui pemagangan dimaksudkan adalah bagian dari sistem pelatihan kerja yang diselenggarakan secara terpadu antara pelatihan di lembaga pelatihan dengan bekerja secara langsung dibawah bimbingan dan pengawasan instruktur atau pekerja/buruh yang lebih berpengalaman, dalam proses produksi barang dan/atau jasa di perusahaan dalam rangka menguasai keterampilan atau keahlian tertentu.

\section{Prinsip Pembinaan Paradigma baru}

Menurut Osborne dan Gaebler dalam Tamba (2004: p94), untuk menghasilkan high quality public goods and services, dapat menggunakan prinsip-prinsip paradigma baru yang meliputi model pembinaan 10 prinsip: (1). Steering rather than rowing; (2). Empower communities to solve their own problem, rather than merely deliver services; (3). Promote and encourage competition rather than monopolies; (4). Be driven by missions rather than rule; (5). Result oriented by funding outcomes rather than outputs; (6). Meet the needs of customer rather those of the bureaucracy; (7). Concentrate on earning money rather than just spending it; (8). Invest in preventing problems rather than curing crises; (9). Decentralize authority rather than build hierarchy; (10). Solve problem by influencing market forces rather than by treating public programs.

\section{Pembinaan Usaha}

Pembinaan usaha meliputi pembinaan dan bantuan aspek pemasaran dan promosi. Turbulensi perubahan lingkungan yang penuh ketidakpastian (uncertainty) selalu menawarkan dua kemungkinan, yaitu peluang emas dan ancaman. Dalam kondisi seperti ini, tentu saja UMKM akan tergilas dengan sendirinya bila tidak dapat mengantisipasi dan memanfaatkan arus perubahan itu. Apalagi di era pasar bebas, UMKM harus siap bersaing dengan para pelaku bisnis dari seluruh penjuru dunia. Secara individu, mereka belum terbiasa dan relatif tidak mampu bersaing di arena pasar yang terbuka, fair, dan transparant. Menurut Dipta (2008), tren ekonomi saat ini yang disebut dengan "new economy" atau "cyber economy" menuntut kita harus mampu menentukan strategi yang jitu dalam memenangkan persaingan. Oleh karena itulah untuk dapat menguasai pasar baik global maupun domestik, maka UKM harus mendapatkan pembinaan usaha yang memadai sehingga mampu bersaing di era "new economy" ini.

\section{Strategi Produk dan Pasar}

Dengan menggunakan konsep Kotler dan Armstrong (1989) terdapat 4 pilihan yang dapat dikembangkan yang merupakan kombinasi dari produk UMKM dengan target pasar yang dituju, yaitu:

a. Penetrasi pasar. Strategi yang dilakukan bagi UMKM yang produknya sudah memasuki 
pasar. Menurut Tamba (2004), program yang cocok untuk strategi ini adalah meningkatkan penampilan (attractiveness) melalui penyediaan kemudahan teknologi pengolahan dan pengemasan.

b. Perluasan pasar. Strategi yang dilakukan bagi UMKM di mana pasar yang ada sudah jenuh. Untuk strategi ini perlu dilakukan review pasar secara geografis terlebih dahulu.

c. Pengembangan produk. Membuat produk baru pada pasar yang ada saat ini. Tentunya perlu dikaji apakah dalam jangka panjang produkproduk yang dihasilkan UMKM tersebut memiliki kelangsungan hidup yang panjang.

d. Diversifikasi. Ini berarti mencari pasar baru dan produk UMKM yang baru. Pilihan ini tentunya high cost. Oleh sebab itu maka perlu bantuan pemerintah dalam hal seperti perijinan, pameran secara gratis, dll

10. Balance Scorecard

Balanced scorecard pada tahap implementasi digunakan untuk mengukur kinerja personel dalam empat perspektif yaitu: Keuangan, customer, proses bisnis, serta pembelajaran dan pertumbuhan. Menurut mulyadi (2001: p63) untuk melipatgandakan kinerja keuangan perusahaan (shareholder value), personel perlu menempuh langkah-langkah strategik berupa pembangunan tiga macam modal (capital) yaitu: firm equity, organizational capital, dan human capital. Hubungan rasional antara ke empat perspektif dapat diilustrasikan pada gambar dibawah ini.

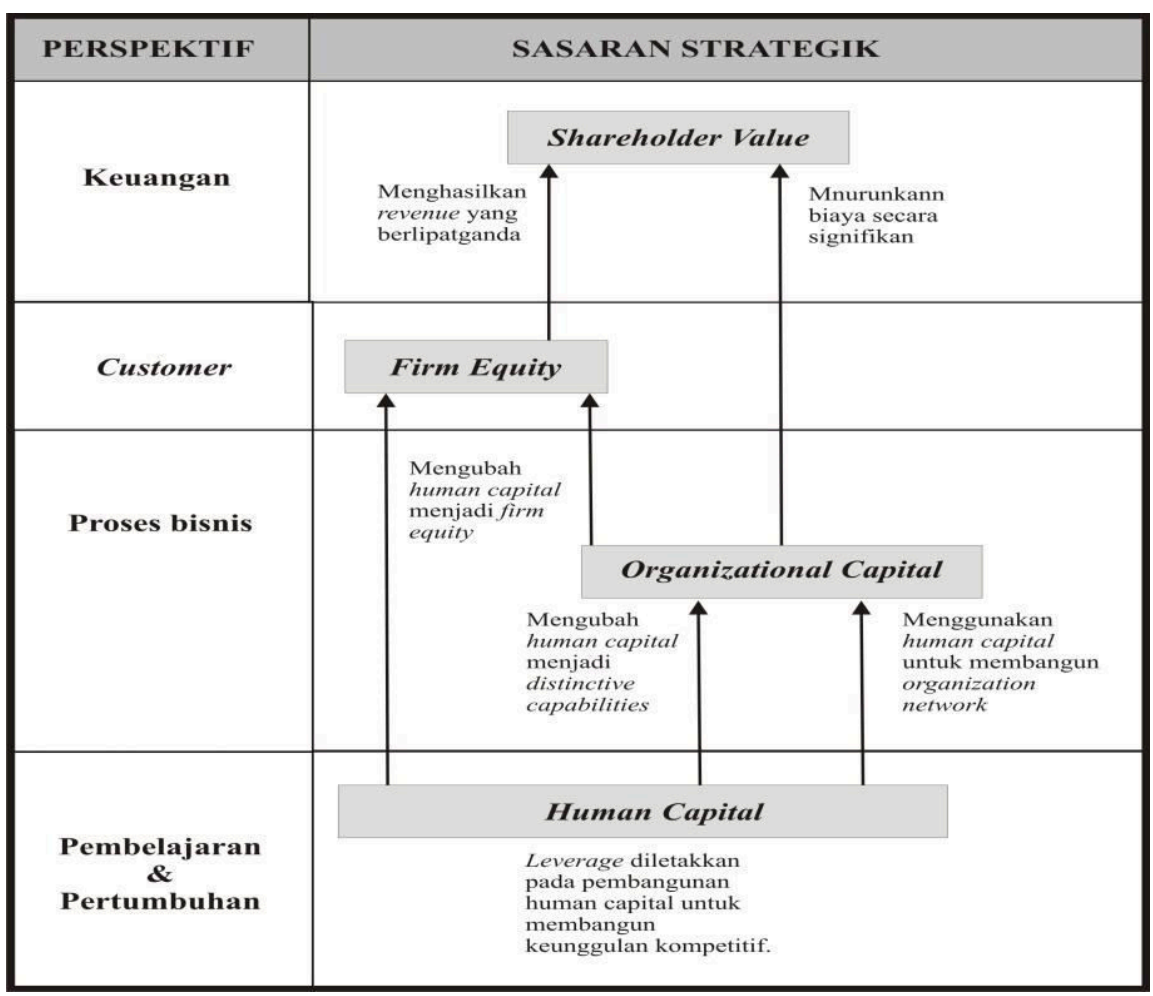

Sumber: Mulyadi (2001)

Gambar 1: Rationale Di Antara Empat Sasaran Strategik 


\section{JURNAL MANAJEMEN VOL. 4 NO. 1 JUNI 2014}

Keberadaan perusahaan ditujukan untuk memberikan kepuasan kepada stakeholders utama yaitu: investors dan customers. Investors dipuasi dengan shareholder value, sedangkan customers dipuasi dengan firm equity. Shareholder value adalah nilai perusahaan dipandang dari persepsi investors, sedangkan Firm equity adalah nilai perusahaan dipandang dari sudut customers, yang ditentukan oleh brand equity (nilai produk) dan firm culture (kultur perusahaan). Untuk memuaskan kedua stakeholders tersebut, perusahaan memerlukan dua modal (capital) yaitu: human capital dan organizational capital. Human capital dibangun melalui pengembangan employee capability dan employee commitment, yang dimanfaatkan untuk membangun firm equity dengan mendesain dan memproduksi barang dan jasa yang menghasilkan value terbaik bagi customers. Human capital juga dimanfaatkan untuk membangun organizational capital untuk menghasilkan proses yang cost effective, sehingga. meningkatkan produktivitas yang berujung melipatgandakan pendapatan. Firm equity akan melipatgandakan pendapatan penjualan, sehingga digabung dengan penurunan biaya dari proses cost effective akan menghasilkan pelipatgandaan shareholder value.

\section{Kerangka Pikir}

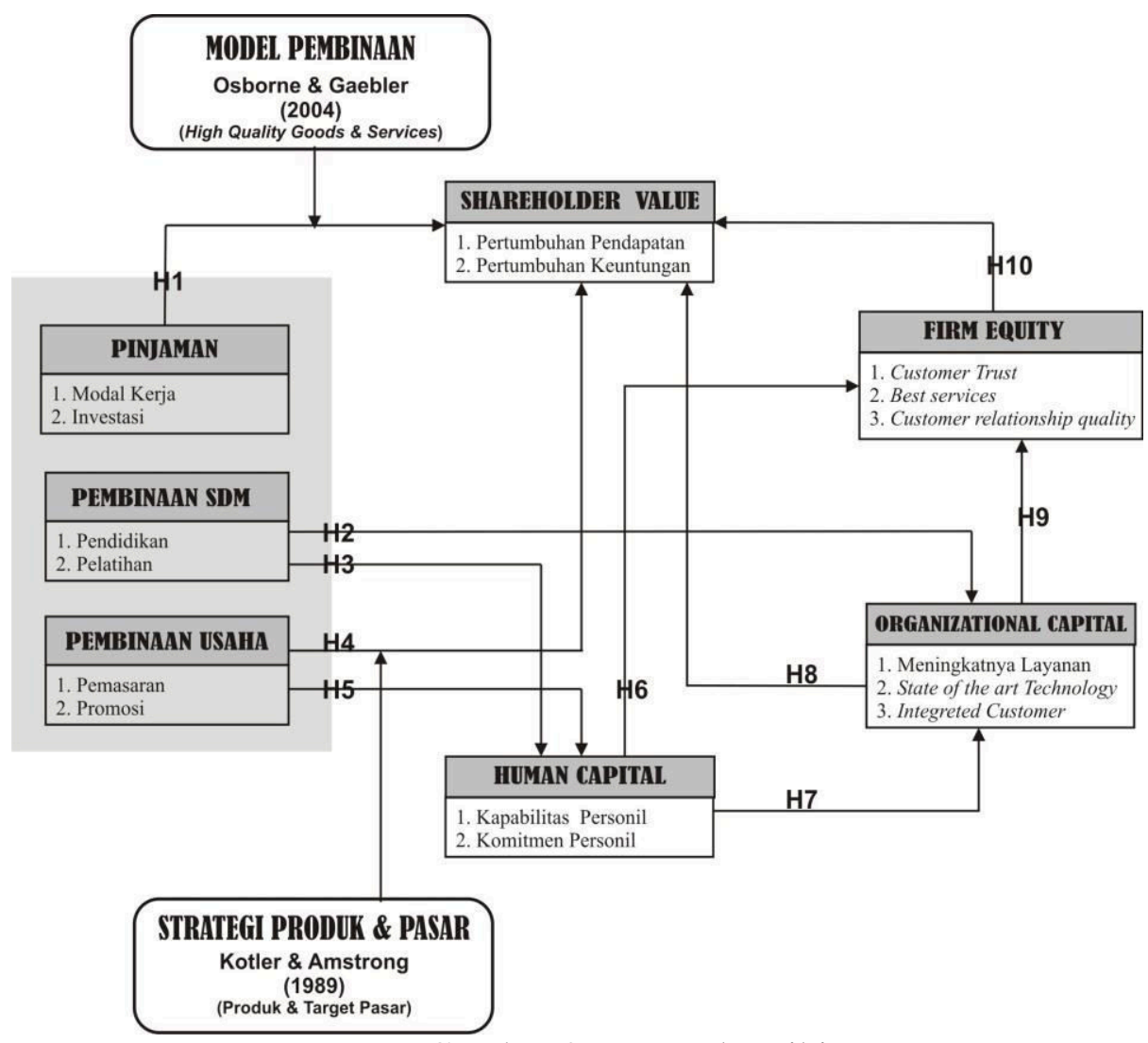

Gambar 2: Kerangka Pikir

Berdasarkan kajian teoritis dan kerangka pikir tersebut diatas, selanjutnya dapat dikembangan hipotesis berikut ini.

H1. Pinjaman dari BUMN berpengaruh terhadap shareholder value

H2. Pembinaan SDM oleh BUMN berpengaruh terhadap Organizational Capital

H3. Pembinaan SDM oleh BUMN berpengaruh terhadap Human Capital

H4. Pembinaan Usaha oleh BUMN berpengaruh terhadap Shareholder Value 
H5. Pembinaan Usaha oleh BUMN berpengaruh terhadap Human Capital

H6. Human Capital berpengaruh terhadap Firm Equity

H7. Human Capital berpengaruh terhadap Organizational Capital

H8. Organizational Capital berpengaruh terhadap Shareholder Value

H9. Organizational Capital berpengaruh terhadap Firm Equity

H10. Firm Equity berpengaruh terhadap Shareholder Value

H11. Pinjaman yang di moderasi Model Pembinaan Paradigma Baru berpengaruh positip terhadap Shareholder Value.

H12. Pembinaan Usaha yang di moderasi Strategi Produk dan Pasar yahg tepat akan berpengaruh terhadap sharegolder Value.

C. METODE PENELITIAN

1. Populasi, Sampel, Pengumpulan Data

Populasi adalah UKM yang menjadi Mitra Binaan BUMN di daerah Kabupaten Sleman berdasarkan data yang tersedia pada http://pkbl.bumn.go.id/ . Sampel ditentukan dengan rumus Slovin, sedangkan metode pengambilan sampel menggunakan metode dan

Definisi purposive sampling dengan kriteria UKM masih beroperasi dan alamat dapat ditemukan. teknik pengumpulan data menggunakan instrument kuesioner.

\section{Variabel Penelitian}

Variabel penelitian yang digunakan dan definisi operasional seperti berikut ini.

\begin{tabular}{|c|c|c|c|c|}
\hline No & Variabel & Notasi & Definisi & Macam \\
\hline 1 & Pinjaman & $\mathrm{X} 1$ & $\begin{array}{l}\text { Adalah pinjaman yang diberikan oleh } \\
\text { BUMN untuk membiayai modal kerja } \\
\text { dan atau pembelian aktiva tetap } \\
\text { (investasi) } \quad \text { dalam r rangka } \\
\text { meningkatkan produksi penjualan } \\
\text { UMKM. }\end{array}$ & Exogen \\
\hline 2 & Pembinaan SDM & $\mathrm{X} 2$ & 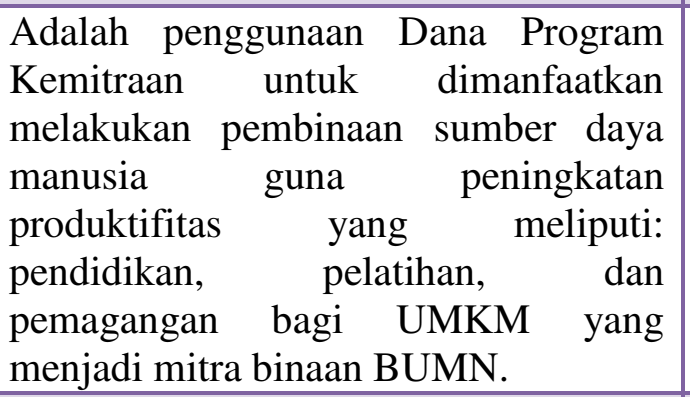 & Exogen \\
\hline 3 & $\begin{array}{l}\text { Pembinaan } \\
\text { Usaha }\end{array}$ & $\mathrm{X} 3$ & $\begin{array}{l}\text { Adalah penggunaan Dana Program } \\
\text { Kemitraan untuk dimanfaatkan } \\
\text { membantu kegiatan pemasaran dan } \\
\text { promosi bagi UMKM yang menjadi } \\
\text { mitra binaan BUMN. }\end{array}$ & Exogen \\
\hline 4 & $\begin{array}{l}\text { Model } \\
\text { Pembinaan }\end{array}$ & $\mathrm{Z} 1$ & $\begin{array}{l}\text { Adalah prinsip-prinsip paradigma baru } \\
\text { yang dikutip Tamba (2004) dari } \\
\text { Osborne dan Gaebler, meliputi } 10 \\
\text { prinsip. }\end{array}$ & Moderating \\
\hline 5 & $\begin{array}{l}\text { Arahan Produk } \\
\&\end{array}$ & $\mathrm{Z2}$ & $\begin{array}{lcr}\text { Menggunakan } & \text { konsep } & \text { Kotler } \quad \& \\
\text { Armstrong } & (1989) & \text { yang }\end{array}$ & Moderating \\
\hline
\end{tabular}


JURNAL MANAJEMEN VOL. 4 NO. 1 JUNI 2014

\begin{tabular}{|c|c|c|c|c|}
\hline & Pasar & & $\begin{array}{l}\text { mengembangkan kombinasi produk } \\
\text { dengan target pasar yang dituju. }\end{array}$ & \\
\hline 6 & $\begin{array}{l}\text { Shareholder } \\
\text { Value }\end{array}$ & Y1 & $\begin{array}{l}\text { adalah nilai perusahaan dipandang dari } \\
\text { persepsi investors atau pemlik usaha } \\
\text { yang diukur dengan pertumbuhan } \\
\text { pendapatan dari UMKM. }\end{array}$ & Endogen \\
\hline 7 & Human Capital & Y2 & $\begin{array}{l}\text { Adalah proses pembelajaran dan } \\
\text { pertumbuhan tenaga kerja yang terlibat } \\
\text { pada UMKM yang dijadikan obyek } \\
\text { penelitian, yang diukur dengan } \\
\text { semakin meningkatnya kapabilitas dan } \\
\text { komitmen SDM. }\end{array}$ & Exogen/Endogen \\
\hline 8 & $\begin{array}{l}\text { Organizational } \\
\text { Capital }\end{array}$ & Y3 & $\begin{array}{l}\text { Adalah proses bisnis internal } \\
\text { organisasi untuk menghasilkan proses } \\
\text { yang cost effective. Dengan cost } \\
\text { effective, akan meningkatkan } \\
\text { produktivitas, } \\
\text { melipatgandakan pendapatan. }\end{array}$ & Exogen/Endogen \\
\hline 9 & Firm Equity & Y4 & $\begin{array}{l}\text { adalah nilai perusahaan dipandang dari } \\
\text { sudut customers, yang ditentukan oleh } \\
\text { brand equity (nilai produk dari sudut } \\
\text { pandang customers) dan firm culture } \\
\text { (kultur perusahaan yang menentukan } \\
\text { kualitas hubungan antara perusahaan } \\
\text { dengan customers). }\end{array}$ & Exogen/Endogen \\
\hline
\end{tabular}

\section{Analisis Data}

Data penelitian ini dilakukan analisis dengan menggunakan statistik deskriptif dan inferensial. Dari statistik deskriptif akan disajikan tabel dan grafik dari data yang telah terkumpul. Sedangkan analisis statistik inferensial dilakukan dengan menggunakan Partial Least Square (PLS) yaitu Structural Equation Modeling (SEM) yang berbasis variance, dengan software SmartPlS ver 2.0.
Cara kerja PLS meliputi dua tahap yaitu: Tahap pertama, outer model yang mengukur validitas dan reliabilitas indikator terhadap variabel laten atau konstruknya. Tahap kedua, inner model yang menggambarkan hubungan antar variabel laten berdasarkan substantive theory. Adapun kriteria model PLS menurut Chin (1998) dalam Ghozali (2008) sebagai berikut:

Tabel 3: Kriteria Model PLS

\begin{tabular}{|l|l|l|}
\hline NO & $\begin{array}{l}\text { MODEL } \\
\text { PENGUKURAN }\end{array}$ & KRITERIA \\
\hline 1 & $\begin{array}{l}\text { Outer Model: } \\
\begin{array}{l}\text { a. Convergent Validity } \\
\text { b. Discriminant Validity }\end{array}\end{array}$ & $\begin{array}{l}\text { a. Nilai loading factor harus diatas 0,50 } \\
\text { betiap indikator harus memiliki nilai loading lebih } \\
\text { tinggi terhadap konstruknya dibandingkan dengan } \\
\text { terhadap konstruk yang lainnya } \\
\text { c. Composite Reliability }\end{array}$ \\
\hline
\end{tabular}




\begin{tabular}{|l|l|l|l|}
\hline & $\begin{array}{l}\text { Inner Model: } \\
\text { a. } \mathrm{R}^{2} \text { untuk variabel } \\
\text { laten endogen. }\end{array}$ & $\begin{array}{l}\text { a. Hasil R2 sebesar 0,67; 0,33; dan 0,19 } \\
\text { mengindikasikan bahwa model "Baik", } \\
\text { b. Estimasi koefisien } \\
\text { parameter. }\end{array}$ & $\begin{array}{l}\text { "Moderat", dan "Lemah". } \\
\text { b. Nilai estimasi hubungan jalur dalam model } \\
\text { struktural harus signifikan. }\end{array}$ \\
\hline
\end{tabular}

\section{HASIL ANALISIS DATA}

\section{Karakteristik Responden}

a. Jumlah sampel

Data penelitian yang diperoleh sebesar 50,71\% atau sebanyak 36 UKM dari sampel data yang direncanakan sebesar 71 seperti tabel berikut ini.

Tabel 4: Rincian Data Penelitian

\begin{tabular}{|c|c|c|}
\hline Keterangan & Jumlah & $\%$ \\
\hline Sampel & $\begin{array}{c}71 \\
\text { UKM }\end{array}$ & 100 \\
\hline Tidak aktif & $(12)$ & 16,90 \\
\hline Pindah alamat & UKM & 8,45 \\
\hline $\begin{array}{ll}\text { Alamat } & \text { Tdk } \\
\text { ditemukan } & \end{array}$ & $\begin{array}{l}\left(\begin{array}{l} \\
\text { UKM }\end{array}\right. \\
(17) \\
\text { UKM }\end{array}$ & 23,94 \\
\hline Data penelitian & $\begin{array}{c}36 \\
\text { UKM }\end{array}$ & 50,71 \\
\hline
\end{tabular}

b. Berdasarkan Jenis UKM

Data penelitian berdasarkan jenis UKM seperti berikut ini.

Tabel 5: Jenis UKM

\begin{tabular}{|c|c|c|}
\hline Keterangan & Jumlah & $\%$ \\
\hline Konveksi & 2 & \\
\hline Makanan & UKM & 5,56 \\
\hline Minuman & 9 & \\
\hline Salon & UKM & 25,00 \\
\hline Advertising & 5 & \\
\hline Mebel & UKM & 13,89 \\
\hline Bahan Bangunan & 2 & \\
\hline Bengkel & UKM & 5,56 \\
\hline Jumlah & 5 & \\
\hline & $\begin{array}{c}\text { UKM } \\
8\end{array}$ & 13,89 \\
\hline & $\begin{array}{l}\text { UKM } \\
5\end{array}$ & 22,22 \\
\hline & $\overline{\mathrm{UKM}}$ & $\underline{13,89}$ \\
\hline & 36 & $\overline{100,00}$ \\
\hline & UKM & \\
\hline
\end{tabular}


UKM yang paling banyak bermitra dengan BUMN bergerak pada usaha makanan \& minuman sebesar $25 \%$, yang disusul dengan usaha bahan bangunan sebesar 22,22\%. Selebihnya seperti Nampak pada tabel diatas.

c. BUMN Mitra

Data penelitian berdasarkan BUMN Mitra seperti berikut ini.

Tabel 6: BUMN Mitra

\begin{tabular}{|c|c|c|}
\hline Keterangan & Jumla & $\%$ \\
\hline PUSRI & 2 & 5,56 \\
\hline PERURI & UKM & 2,78 \\
\hline BTN & 1 & 22,22 \\
\hline Jasa Raharja & UKM & 58,32 \\
\hline Asuransi Ekspor & 8 & 5,56 \\
\hline Indonesia & UKM & 5,56 \\
\hline JAMSOSTEK & 21 & 100,00 \\
\hline \multirow[t]{7}{*}{ Jumlah } & UKM & \\
\hline & 2 & \\
\hline & UKM & \\
\hline & $\underline{2}$ & \\
\hline & $\underline{\mathrm{UKM}}$ & \\
\hline & 36 & \\
\hline & UKM & \\
\hline
\end{tabular}

BUMN yang paling banyak bermitra dengan UKM adalah Jasa Raharja sebesar 58,32\%, yang disusul dengan BTN sebesar 22,22\%. Selebihnya seperti Nampak pada tabel diatas.

\section{Analisis Deskriptif}

Deskripsi dari data penelitian untuk masing-masing variabel dapat digambarkan dalam visualisasi tabel dan grafik seperti berikut ini.

a. Pinjaman (X1)

Pinjaman modal kerja maupun investasi yang dikucurkan BUMN mitra kepada para UKM nampak pada tabel berikut ini.

Tabel 7: Pinjaman

\begin{tabular}{|c|c|c|c|}
\hline Jenis & Rerata & Jumlah & $\%$ \\
\hline \multirow{6}{*}{$\begin{array}{l}\text { Modal } \\
\text { Kerja }\end{array}$} & $9.5 \mathrm{Jt}$ & 18 & 50,00 \\
\hline & $18.5 \mathrm{Jt}$ & UKM & 50,00 \\
\hline & & 18 & $\overline{100,00}$ \\
\hline & & $\underline{\mathrm{UKM}}$ & \\
\hline & & 36 & \\
\hline & & UKM & \\
\hline \multirow{8}{*}{ Investasi } & 0 & 26 & 72,22 \\
\hline & $9.5 \mathrm{Jt}$ & UKM & 11,11 \\
\hline & $18.5 \mathrm{Jt}$ & 4 & 16,67 \\
\hline & & UKM & $\overline{100,00}$ \\
\hline & & 6 & \\
\hline & & $\underline{\mathrm{UKM}}$ & \\
\hline & & $\overline{36}$ & \\
\hline & & UKM & \\
\hline
\end{tabular}


Seperti terlihat pada tabel diatas, pinjaman yang disalurkan BUMN kepada UKM $50 \%$ dengan rata-rata $\mathrm{Rp}$ 9,5 juta dan $50 \%$-nya lagi ratarata $\mathrm{Rp} 18,5$ juta. Sedangkan pinjaman investasi, $72,22 \%$ UKM tidak menerima pinjaman ini, $16,67 \%$ menerima dengan rata-rata $\mathrm{Rp} 18,5$ juta, sisanya $11 \%$ menerima sebesar rata-rata Rp. 9,5 juta.

Tabel 8: Pelatihan b. Pembinaan SDM (X2)

Pembinaan SDM oleh BUMN mitra hanya dalam bentuk pelatihan. Pembinaan dalam bentuk pendidikan maupun pemagangan tidak dilakukan. Adapun pelatihan yang dilakukan hanya terhadap 28 UKM atau sebesar 77,78\%, sisanya sebesar 8 UKM tidak pernah diberikan pembinaan pelatihan.

\begin{tabular}{|lll|}
\hline Keterangan & Jumlah & \multicolumn{1}{c|}{$\%$} \\
\hline Diikutkan Pelatihan & \multicolumn{1}{c|}{ ( $)$} & 22,22 \\
Tidak diikutkan & UKM & $\underline{77,78}$ \\
Pelatihan & $\underline{28}$ & 100,00 \\
& UKM & \\
& 36 & \\
& UKM & \\
\hline
\end{tabular}

c. Pembinaan Usaha (X3)

Bantuan dalam bentuk selebihnya sebesar $66,67 \%$ atau pemasaran dan promosi sebanyak 24 UKM tidak dilakukan hanya terhadap 12 mendapatkan bantuan.

UKM atau sebesar 33,33\%,

Tabel 9: Pembinaan Pemasaran

\begin{tabular}{|lll|}
\hline Keterangan & Jumlah & $\%$ \\
\hline Dibantu & 12 & 33,33 \\
pemasaran & UKM & $\underline{66,67}$ \\
Tidak dibantu & $\underline{24}$ & 100,00 \\
& UKM & \\
& 36 & \\
& UKM \\
\hline
\end{tabular}

Tabel 10: Pembinaan Promosi

\begin{tabular}{|llc|}
\hline Keterangan & Jumlah & \multicolumn{1}{c|}{} \\
\hline Dibantu & 12 & 33,33 \\
promosi & UKM & $\underline{66,67}$ \\
Tidak & $\underline{24}$ & 100,00 \\
dibantu & UKM & \\
& 36 & \\
& UKM \\
\hline
\end{tabular}

d. Shareholder Value (Y1)

Diukur dengan menggunakan peningkatan rata-rata pendapatan UKM, menunjukkan sebesar $22,22 \%$ atau sebanyak 8 UKM tidak mengalami peningkatan, $75 \%$ atau 27 UKM menyatakan mengalami peningkatan rata- 
rata sebesar 3,8\%, dan sebesar $2,78 \%$ mengalami peningkatan rata-rata $5,6 \%$ seperti tabel berikut ini.

Tabel 11: Pendapatan

\begin{tabular}{|c|c|c|}
\hline Keterangan & Jumla & $\%$ \\
\hline Tetap & 8 & 22,22 \\
\hline Meningkat rerata & UKM & 75,00 \\
\hline $3,8 \%$ & 27 & 2,78 \\
\hline Meningkat rerata & UKM & $1 \overline{00,00}$ \\
\hline $5,6 \%$ & 1 & \\
\hline & $\overline{\mathrm{UKM}}$ & \\
\hline & 36 & \\
\hline & UKM & \\
\hline
\end{tabular}

\section{e. Human Capital (Y2)}

Diukur menggunakan adanya perubahan kapabilitas (kemampuan). Hasil penelitian menunjukkan sebesar 72,23\% atau sebanyak 26 UKM tidak

hanya sebesar $27,77 \%$ atau sebanyak 10 UKM yang mengalami peningkatan seperti ditunjukan pada tabel berikut ini.

ada peningkatan atau tetap, dan

Tabel 12: Kemampuan SDM

\begin{tabular}{|lll|}
\hline Keterangan & Jumlah & $\%$ \\
\hline Tetap & 26 & 72,23 \\
Meningkat & UKM & $\underline{27,77}$ \\
& $\underline{10}$ & 100,00 \\
& UKM & \\
& 36 & \\
& UKM & \\
\hline
\end{tabular}

\section{f. Organizational Capital (Y3)}

Dari variabel ini, sebanyak 20 UKM atau sebesar 55,56\% menyatakan layanan dan teknologi terjadi peningkatan, sedangkan 16 UKM atau sebesar 44,44\% menyatakan tidak terjadi peningkatan. Sementara itu indikator

integrated customer service yang menyatakan meningkat hanya sebesar $27,77 \%$ atau sebanyak 10 UKM, sedangkan sebesar $72,23 \%$ atau sebanyak 26 UKM menyatakan tidak ada peningkatan. Lihat tabel berikut ini.

Tabel 13: Organizational Capital

\begin{tabular}{|lcc|}
\hline Keterangan & Jumlah & $\%$ \\
\hline$\underline{\text { Layanan }}$ & & \\
Tetap & 16 & 44,44 \\
& UKM & $\underline{55,56}$ \\
& $\underline{20}$ & 100,00 \\
Teknologi & 36 & \\
Tetap & UKM & 44,44 \\
Meningkat & & $\underline{55,56}$ \\
\hline
\end{tabular}




\begin{tabular}{|llr|}
\hline & 16 & 100,00 \\
Integreted & UKM & \\
$\frac{\text { Customer }}{\text { Tetap }}$ & $\underline{20}$ & \\
Meningkat & UKM & 72,23 \\
& 36 & $\underline{27,77}$ \\
& UKM & 100,00 \\
& 26 & \\
& UKM & \\
& 10 & \\
& UKM & \\
& 36 & \\
& UKM & \\
\hline
\end{tabular}

\section{g. Firm Equity (Y4)}

Diukur dengan indikator trust, best service, dan relationship. Dari variabel ini, sebanyak 28 UKM atau sebesar $77,78 \%$ menyatakan terjadi peningkatan trust, dan hanya 8 UKM atau sebesar $22,22 \%$ menyatakan tidak terjadi peningkatan. Namun demikian peningkatan trust tidak diikuti secara seimbang adanya peningkatan best services, di mana hanya sebesar $27,77 \%$ atau sebanyak 10 UKM yang menyatakan adanya peningkatan best services, selebihnya menyatakan tidak terjadi peningkatan. Sedangkan indikator relationship menunjukan adanya peningkatan pada 25 UKM atau sebesar 69,44\%. Lihat tabel berikut ini.

Tabel 14: Firm Equity

\begin{tabular}{|lll|}
\hline Keterangan & Jumlah & $\%$ \\
\hline$\underline{\text { Trust }}$ & & \\
Tetap & 8 & 22,22 \\
Meningkat & UKM & $\underline{77,78}$ \\
& $\underline{28}$ & 100,00 \\
& UKM & \\
$\frac{\text { Best }}{\text { Services }}$ & 36 & \\
$\frac{\text { UKM }}{\text { Tetap }}$ & & 72,23 \\
Meningkat & & $\underline{27,77}$ \\
& 26 & \\
& UKM & \\
$\frac{\text { Relationship }}{\text { Tetap }}$ & $\underline{10}$ & 30,56 \\
Meningkat & UKM & $\underline{69,44}$ \\
& UKM & 100,00 \\
& 11 & \\
& UKM & \\
& $\underline{25}$ & \\
& UKM & \\
& 36 & \\
& UKM & \\
\hline
\end{tabular}




\section{h. Model Pembinaan}

Model pembinaan tidak sepenuhnya mengikuti paradigma baru yang ditawarkan oleh Osborne dan Gaebler seperti tampak pada tabel dibawah ini.

Tabel 15: Model Pembinaan

\begin{tabular}{|lll|} 
No & Cara Pembinaan & $\begin{array}{l}\text { Sesuai Model } \\
\text { Osborne } \\
\text { Gaebler } \\
\mathbf{( \% )}\end{array}$ \\
\hline $\mathbf{1}$ & BUMN tidak ikut memasarkan produk & 66,67 \\
\hline $\mathbf{2}$ & $\begin{array}{l}\text { BUMN tidak ikut menyelesaikan masalah } \\
\text { mitra }\end{array}$ & 100,00 \\
\hline $\mathbf{3}$ & BUMN mendorong agar mitra bersaing & 100,00 \\
\hline $\mathbf{4}$ & BUMN tidak kaku terhadap aturan & 100,00 \\
\hline $\mathbf{5}$ & BUMN mendorong kinerja maksimal & 100,00 \\
\hline $\mathbf{6}$ & BUMN tidak diuntungkan dengan kemitraan & 72,22 \\
\hline $\mathbf{7}$ & $\begin{array}{l}\text { BUMN membantu agar pemasaran tepat } \\
\text { sasaran }\end{array}$ & 100,00 \\
\hline $\mathbf{8}$ & $\begin{array}{l}\text { BUMN selalu mengingkatkan hal-hal yang } \\
\text { dapat merugikan }\end{array}$ \\
\hline $\mathbf{9}$ & $\begin{array}{l}\text { BUMN memberikan keleluasaan penggunaan } \\
\text { pinjaman }\end{array}$ \\
\hline $\mathbf{1 0}$ & BUMN perhatian atas kondisi pasar \\
\hline
\end{tabular}

\section{i. Pembinaan Strategi Pemasaran}

Cara pembinaan strategi pemasaran menunjukkan kondisi seperti tabel dibawah ini.

Tabel 16: Pembinaan Strategi Pemasaran

\begin{tabular}{|llr|}
\hline No & Cara Pembinaan & $\mathbf{\%}$ \\
\hline $\mathbf{1}$ & $\begin{array}{l}\text { BUMN mengarahkan untuk mendapatkan pelanggan } \\
\text { baru }\end{array}$ & 33,33 \\
\hline $\mathbf{2}$ & $\begin{array}{l}\text { BUMN mengarahkan untuk membuka pasar baru dan } \\
\text { atau produk baru }\end{array}$ & 44,44 \\
\hline 3 & Diversifikasi & 22,23 \\
\hline & Jumlah & 100,00 \\
\hline
\end{tabular}

\section{Analisis Inferensial}

Analisis inferensial menggunakan teknik Partial Least Square (PLS) dilakukan dua tahap. Tahap Pertama, melakukan eksekusi model pengukuran untuk mengetahui validitas dan reliabilitas dari indikator terhadap konstruknya. Tahap Kedua, eksekusi model struktural yang pada hakekatnya adalah menguji hipotesis penelitian.

a. Model Pengukuran

Model pengukuran dilakukan untuk menguji apakah indikator yang digunakan valid dan reliabel. Model sebelum diuji nampak seperti gambar berikut ini 


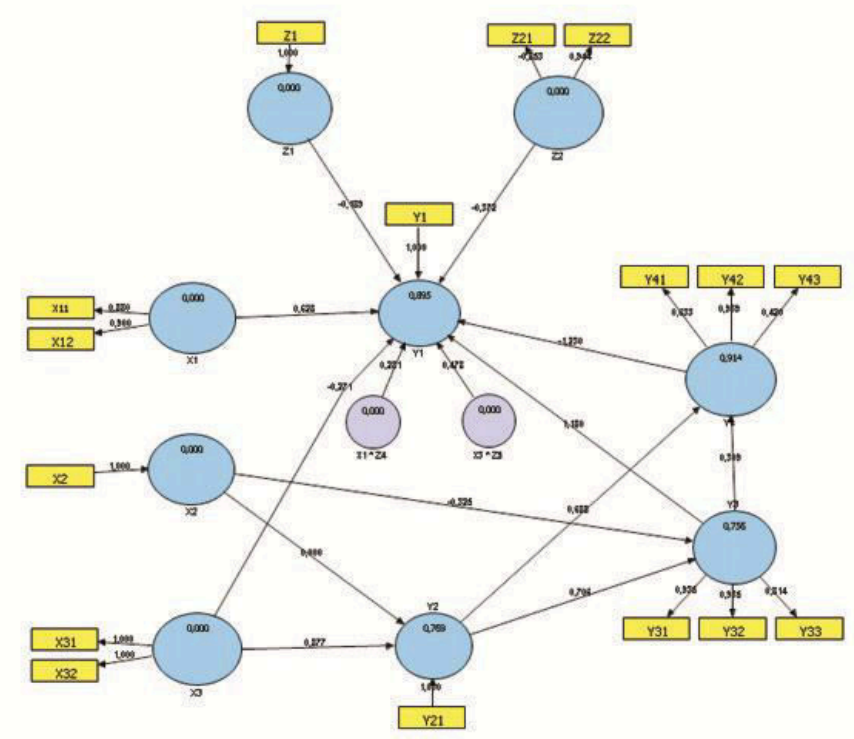

Gambar 3: Model Sebelum Uji Pengukuran

Uji model pengukuran yang dilakukan meliputi: convergent validity, discriminant validity, dan composite reliability sebagai berikut:

Tabel 17: Convergent Validity

\begin{tabular}{|l|l|l|l|l|l|}
\hline & X1 & $\mathbf{X 3}$ & $\mathbf{Y 3}$ & $\mathbf{Y 4}$ & Ket \\
\hline X11 & 0,879 & & & & Valid \\
\hline X12 & 0,900 & & & & Valid \\
\hline X31 & & 1,000 & & & Valid \\
\hline X32 & & 1,000 & & & Valid \\
\hline Y31 & & & 0,932 & & Valid \\
\hline Y32 & & & 0,932 & & Valid \\
\hline Y33 & & & 0,818 & & Valid \\
\hline Y41 & & & & 0,633 & Valid \\
\hline Y42 & & & & 0,939 & Valid \\
\hline Y43 & & & & 0,419 & $\begin{array}{l}\text { Tidak } \\
\text { Valid }\end{array}$ \\
\hline
\end{tabular}

Sumber: Output Smartpls

Tabel 18: Discriminant Validity

\begin{tabular}{|l|l|l|l|l|l|}
\hline & X1 & $\mathbf{X 3}$ & $\mathbf{Y 3}$ & $\mathbf{Y 4}$ & Ket \\
\hline X11 & $\mathbf{0 , 8 7 9}$ & 0,707 & 0,264 & 0,412 & Valid \\
\hline X12 & $\mathbf{0 , 9 0 0}$ & 0,828 & 0,768 & 0,895 & Valid \\
\hline X31 & 0,864 & $\mathbf{1 , 0 0 0}$ & 0,649 & 0,752 & Valid \\
\hline X32 & 0,864 & $\mathbf{1 , 0 0 0}$ & 0,649 & 0,752 & Valid \\
\hline Y31 & 0,307 & 0,395 & $\mathbf{0 , 9 3 5}$ & 0,670 & Valid \\
\hline Y32 & 0,307 & 0,395 & $\mathbf{0 , 9 3 5}$ & 0,670 & Valid \\
\hline Y33 & 0,886 & 0,877 & 0,813 & $\mathbf{0 , 9 3 9}$ & $\begin{array}{l}\text { Tidak } \\
\text { Valid }\end{array}$ \\
\hline
\end{tabular}




\begin{tabular}{|l|l|l|l|l|l|}
\hline Y41 & 0,040 & 0,094 & 0,558 & $\mathbf{0 , 6 3 3}$ & Valid \\
\hline Y42 & 0,886 & 0,877 & 0,813 & $\mathbf{0 , 9 3 9}$ & Valid \\
\hline Y43 & - & - & 0,355 & $\mathbf{0 , 4 1 9}$ & Valid \\
\hline \multicolumn{6}{|c|}{ Sumber: Output Smartpls } \\
0,087 & 0,0 .
\end{tabular}

Tabel 19: Composite Reliability

\begin{tabular}{|l|l|l|}
\hline INDIKATOR & LOADING & STATUS \\
\hline $\mathrm{X} 1$ & 0,884 & Reliabel \\
\hline $\mathrm{X} 3$ & 1,000 & Reliabel \\
\hline $\mathrm{Y} 3$ & 0,924 & Reliabel \\
\hline $\mathrm{Y} 4$ & 0,720 & Reliabel \\
\hline
\end{tabular}

Sumber: Output Smartpls

Berdasarkan uji pengukuran diatas, indikator yang dinyatakan tidak valid adalah: Y33 dan Y43, dikeluarkan dari model sehingga model tampak seperti gambar dibawah ini.

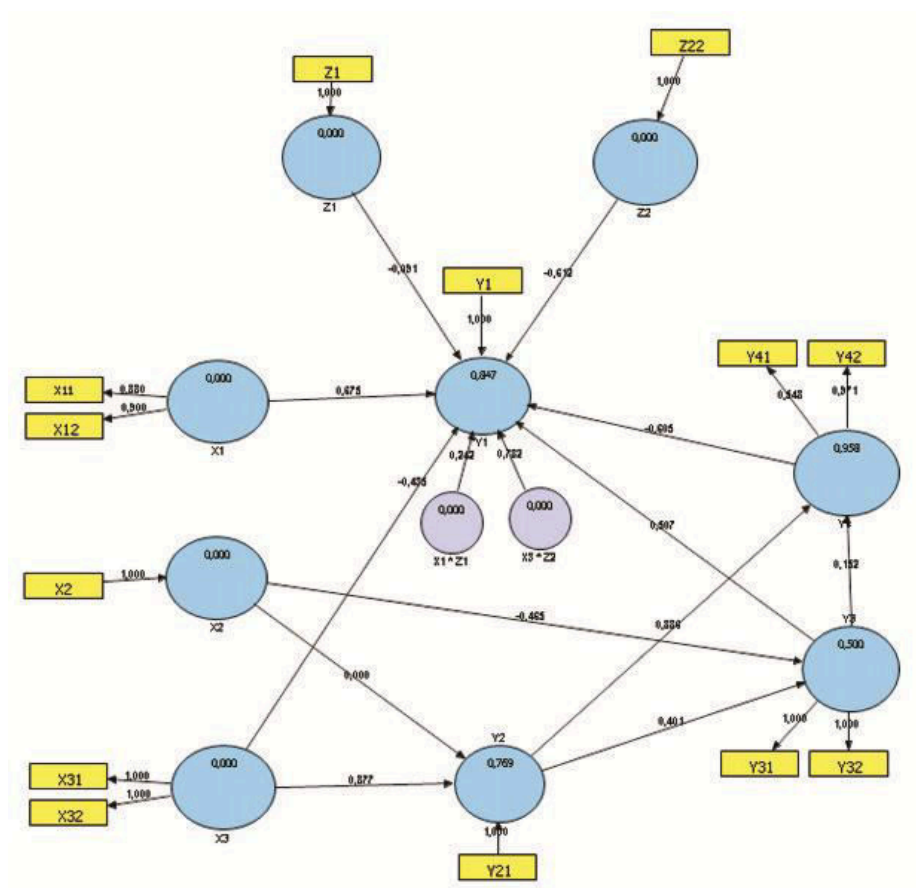

Gambar 4: Model Setelah Uji Pengukuran

b. Model Struktural

Eksekusi PLS Algorithm dan bootstrapping setelah uji pengukuran, menghasilkan inner model atau model struktural yang meliputi: (1). $\mathrm{R}^{2}$ (Uji Model Struktural); dan (2) Koefisien Jalur (Uji Hipotesis). 
Tabel 20: $\mathrm{R}^{2}$

\begin{tabular}{|l|l|lc|}
\hline & $\mathbf{R}^{2}$ & \multicolumn{2}{|l|}{ Goodness Of Fit } \\
\hline Shareholder Value & 0,847 & $\begin{array}{l}\text { Model Fit } \\
\text { (Bagus) }\end{array}$ \\
\hline Human Capital & 0,769 & $\begin{array}{l}\text { Model } \\
\text { (Bagus) }\end{array}$ & Fit \\
\hline $\begin{array}{l}\text { Organizational } \\
\text { Capital }\end{array}$ & 0,500 & Model Moderat \\
\hline Firm Equity & 0,985 & $\begin{array}{l}\text { Model Fit } \\
\text { (Bagus) }\end{array}$ \\
\hline
\end{tabular}

Tabel 21: Inner Model (Model Struktural)

\begin{tabular}{|l|l|l|l|l|}
\hline HIPOTESIS & $\begin{array}{l}\text { VARIABEL } \\
\text { DIUJI }\end{array}$ & KOEFISIEN & $\begin{array}{l}\text { T- } \\
\text { Stat. }\end{array}$ & KETERANGAN \\
\hline $\mathrm{H} 1$ & $\mathrm{X} 1 \rightarrow \mathrm{Y} 1$ & 0,675 & 2,069 & Sig. \\
\hline $\mathrm{H} 2$ & $\mathrm{X} 2 \rightarrow \mathrm{Y} 3$ & $-0,465$ & 6,658 & Tidak Sig. \\
\hline $\mathrm{H} 3$ & $\mathrm{X} 2 \rightarrow \mathrm{Y} 2$ & 0,000 & 0,000 & Tidak Sig. \\
\hline H4 & $\mathrm{X} 3 \rightarrow \mathrm{Y} 1$ & $-0,435$ & 1,145 & Tidak Sig. \\
\hline H5 & $\mathrm{X} 3 \rightarrow \mathrm{Y} 2$ & 0,877 & 17,417 & Sig. \\
\hline H6 & $\mathrm{Y} 2 \rightarrow \mathrm{Y} 4$ & 0,886 & 22,712 & Sig. \\
\hline H7 & $\mathrm{Y} 2 \rightarrow \mathrm{Y} 3$ & 0,947 & 22,712 & Sig. \\
\hline H8 & $\mathrm{Y} 3 \rightarrow \mathrm{Y} 1$ & 0,506 & 2,161 & Sig. \\
\hline $\mathrm{H} 9$ & $\mathrm{Y} 3 \rightarrow \mathrm{Y} 4$ & 0,152 & 3,235 & Sig. \\
\hline $\mathrm{H} 10$ & $\mathrm{Y} 4 \rightarrow \mathrm{Y} 1$ & $-0,605$ & 1,517 & Tidak Sig. \\
\hline $\mathrm{H} 11$ & $\mathrm{X} 1 * \mathrm{Z} 1 \rightarrow \mathrm{Y} 1$ & 0,241 & 1,498 & Tidak Sig. \\
\hline $\mathrm{H} 12$ & $\mathrm{X} 3 * \mathrm{Z} 2 \rightarrow \mathrm{Y} 1$ & 0,781 & 4,252 & Sig. \\
\hline
\end{tabular}

Sumber: Output Smartpls

$\mathrm{t} \_$tabel $=1,697(\mathrm{n}=36, \mathrm{k}=5, \alpha=0,05)$.

\section{E. PEMBAHASAN}

\section{Uji Model Struktural}

a. Model pengaruh Pinjaman, Pembinaan Usaha,

Organizational Capital, dan Firm Equity secara simultan terhadap Shareholder Value memberikan nilai $\mathrm{R}^{2}$ sebesar 0,847 (Model Fit). Hal tersebut dapat diinterprestasikan bahwa variabilitas konstruk Shareholder Value dapat dijelaskan oleh konstruk Pinjaman, Pembinaan Usaha, Organizational Capital, dan Firm Equity sebesar 87,5\%, sedang sisanya sebesar $12,5 \%$ dipengaruhi oleh variabel lain yang tidak terdapat dalam model.

b. Model pengaruh Pembinaan SDM dan Pembinaan Usaha secara simultan berpengaruh kuat (model fit) terhadap Human Capital dengan $\mathrm{R}^{2}$ sebesar 0,769. Hal tersebut dapat diinterprestasikan bahwa variabilitas konstruk Human Capital dapat dijelaskan oleh konstruk Pembinaan SDM dan Pembinaan Usaha sebesar $76,9 \%$, sedang sisanya sebesar $23,1 \%$ dipengaruhi oleh variabel lain yang tidak terdapat dalam model. Pembinaan SDM secara parsial tidak berpengaruh terhadap human capital, akan tetapi secara simultan dengan Pembinaan Usaha menjadi model yang kuat. Hal ini disebabkan kedua pembinaan itu dapat saling 
melengkapi dalam meningkatkan human capital.

c. Model pengaruh Pembinaan SDM dan Human Capital secara simultan berpengaruh moderat terhadap Organizational Capital dengan $\mathrm{R}^{2}$ sebesar 0,500. Hal tersebut dapat diinterprestasikan bahwa variabilitas konstruk Organizational Capital dapat dijelaskan oleh konstruk Pembinaan SDM dan Human Capital sebesar 50\%, sedang sisanya sebesar $50 \%$ dipengaruhi oleh variabel lain yang tidak terdapat dalam model. Pengaruh moderat ini terjadi karena Pembinaan SDM yang dilakukan oleh BUMN Mitra tidak dilakukan secara maksimal.

d. Model pengaruh Human Capital dan Organizational Capital secara simultan berpengaruh sangat kuat (model fit) terhadap Firm Equity dengan $\mathrm{R}^{2}$ sebesar 0,958. Hal tersebut dapat diinterprestasikan bahwa variabilitas konstruk Firm Equity dapat dijelaskan oleh konstruk Human Capital dan Organizational Capital sebesar $95,8 \%$, sedang sisanya sebesar $4,2 \%$ dipengaruhi oleh variabel lain yang tidak terdapat dalam model. Pembinaan BUMN Mitra tidak banyak merubah human capital dan organizational capital. Dari aspek human capital, sebagaimana ditunjukkan pada analisis deskriptif bahwa 72,23\% kemampuan SDM tidak berubah. Dari aspek organizational capital, Layanan dan Teknologi dinyatakan sebesar $44,44 \%$ tidak ada perubahan, demikian pula dengan Integrasi Layanan dinyatakan tidak terjadi perubahan sebesar $72,23 \%$. Walaupun relatif tidak terjadi perubahan yang berarti, namun human capital dan organizational capital mampu menjadi model yang kuat berpengaruh terhadap firm equity. Hal ini terjadi karena kemampuan internal UKM itu sendiri dalam hal relationship dan manajerial.

\section{Uji Hipotesis}

\section{H1 Pinjaman dari BUMN berpengaruh terhadap Shareholder Value.}

Hipotesis ini terbukti, hasil penelitian menunjukan bahwa Pinjaman BUMN berpengaruh positip dan signifikan terhadap Shareholder Value dengan koefisien parameter sebesar 0,675 . Walaupun nilai pinjaman relatif kecil namun masih dapat mendorong meningkatnya shareholder value. Hal ini dimungkinkan karena pinjaman tersebut diberikan pada usaha mikro yang membutuhkan tambahan modal kerja. Pinjaman investasi hanya diberikan pada sebagian UKM yaitu sebesar 27,78\%, selebihnya $72,22 \%$ tidak diberi bantuan pinjaman investasi.

H2. Pembinaan SDM oleh BUMN berpengaruh terhadap Organizational Capital

Hipotesis ini tidak terbukti. Pembinaan SDM tidak mendorong meningkatnya organizational capital (layanan, penggunaan teknologi, dan proses layanan pelanggan yang terintegrasi), hal ini disebabkan karena kurangnya pembinaan yang dilakukan. Pemberian pelatihan hanya diberikan kepada 22,22\% UKM, selebihnya $77,78 \%$ tidak diberikan pelatihan. Selain itu, 
BUMN Mitra juga tidak memberikan bantuan untuk pendidikan dan pemagangan.

H3. Pembinaan SDM oleh BUMN berpengaruh terhadap Human Capital

Hipotesis ini tidak terbukti, Seperti telah disampaikan diatas hal tersebut disebabkan kurangnya pembinaan yang dilakukan. Pemberian pelatihan hanya diberikan kepada $22,22 \%$ UKM, selebihnya 77,78\% tidak diberikan pelatihan. Selain itu, BUMN Mitra juga tidak memberikan bantuan untuk pendidikan dan pemagangan.

H4. Pembinaan Usaha oleh BUMN berpengaruh terhadap Shareholder Value Hipotesis ini tidak terbukti. Hal ini disebabkan kurangnya bantuan terhadap kegiatan pemasaran dan promosi yang hanya diberikan kepada $66,67 \%$ UKM, selebihnya 33,33\% tidak diberikan bantuan pemasaran dan promosi.

H5. Pembinaan Usaha oleh BUMN berpengaruh terhadap Human Capital

Hipotesis ini terbukti, hasil penelitian menunjukan bahwa Pembinaan Usaha berpengaruh positip dan signifikan terhadap Human Capital dengan koefisien parameter sebesar 0,877. Meskipun Pembinaan Usaha tidak mendorong meningkatnya shareholder value (H4), namun mampu memberikan pengaruh yang signifikan terhadap meningkatnya kemampuan SDM (human capital). Hal ini disebabkan karena bantuan semacam itu menarik dan memberikan pengetahuan tersendiri bagi SDM.
H6. Human Capital berpengaruh terhadap Firm Equity

Hipotesis ini terbukti. Hal tersebut terjadi karena pelatihan pada umumnya hanya terbatas pada ketrampilan berproduksi. Sementara itu, meningkatnya firm equity cenderung berkaitan dengan kemampuan relationship. Dengan kata lain bahwa kinerja yang baik dari human capital bukan disebabkan karena pembinaan SDM oleh BUMN Mitra, akan tetapi disebabkan oleh kemampuan relationship dari SDM yang terlibat pada UKM itu sendiri.

H7. Human Capital berpengaruh terhadap

Organizational

\section{Capital}

Hipotesis ini terbukti. Dalam hal ini, ternyata human capital (kemampuan SDM) berpengaruh positip dan signifikan terhadap organizational capital (kualitas layanan, state of the art tecnology, dan integrated customer service) walaupun proses pembinaan (pelatihan) sangat terbatas dan tidak berpengaruh terhadap human capital. Seperti disampaikan diatas bahwa kinerja yang baik dari human capital bukan disebabkan karena pembinaan SDM oleh BUMN Mitra, akan tetapi disebabkan oleh kemampuan manajerial yang ada pada UKM itu sendiri.

H8. Organizational Capital berpengaruh terhadap Shareholder Value

Hipotesis ini terbukti. Sebagaimana disampaikan diatas (H7) bahwa pengaruh positip organizational capital terhadap shareholder value bukan disebabkan karena 
keberhasilan pembinaan

BUMN Mitra, akan tetapi disebabkan karena kemampuan internal dari UKM itu sendiri.

H9. Organizational Capital berpengaruh terhadap Firm Equity

Hipotesis ini terbukti. Seperti disampaikan diatas bahwa pengaruh positip organizational capital terhadap Firm Equity bukan disebabkan karena keberhasilan pembinaan BUMN Mitra, akan tetapi disebabkan karena kemampuan internal dari UKM itu sendiri.

H10. Firm Equity berpengaruh terhadap Shareholder Value Hipotesis ini tidak terbukti. Hal ini terjadi karena proses pembelajaran dan proses bisnis tidak berjalan secara maksimal dan cenderung menurun, sehingga menyebabkan peran firm equity juga menurun. Artinya bahwa pembinaan SDM yang dilakukan BUMN Mitra tidak maksimal, di mana trust dan relationship bagus, tetapi justru best service kurang sebagai pendorong shareholder value.

H11. Pinjaman yang di moderasi Model Pembinaan Paradigma Baru berpengaruh positip terhadap Shareholder Value.

Hasil penelitian menunjukkan bahwa Efek Moderasi Model Pembinaan terhadap Pinjaman justru melemahkan

\section{F. SIMPULAN \& SARAN}

\section{SIMPULAN}

1. Pinjaman BUMN berpengaruh positip dan signifikan terhadap Shareholder Value dengan koefisien parameter sebesar 0,675 (2,069). Namun tidak berdampak luas seperti memberikan kontribusi pada pengaruhnya terhadap shareholder value dari koefisien parameter $(0,675)$ menjadi $(0,241)$ dan tidak signifikan (t statistik=1,498). Hal ini terjadi karena adanya indikasi bahwa model pembinaan yang dilakukan tidak sepenuhnya dilakukan berdasarkan prinsip-prinsip paradigma baru. Sebagaimana pada analisis deskrptif, prinsip No.1 hanya dilakukan $66,67 \%$, prinsip No. 6 (72,22\%), dan prinsip No. 8 (27,78\%).

H12. Pembinaan Usaha yang di moderasi Strategi Produk dan Pasar yahg tepat akan berpengaruh terhadap sharegolder Value.

Hasil penelitian menunjukkan bahwa Efek Moderasi Arahan Strategi Pemasaran terhadap Pembinaan Usaha memperkuat pengaruhnya terhadap shareholder value dari koefisien parameter $(-0,435)$ menjadi $(0,781)$ dan signifikan (t statistik= 4,252). Hal ini menunjukkan bahwa arahan strategi pemasaran yang dipilih relevan dengan UKM terkait. Arahan yang diberikan sebesar $33,33 \%$ untuk mendapatkan Pelanggan Baru, 44,44\% untuk membuka pasar baru dan atau produk Baru, dan 22,23\% diversifikasi. pertumbuhan ekonomi, membuka lapangan kerja baru, dll.

2. Pembinaan SDM tidak terbukti berpengaruh terhadap organizational capital maupun human capital, karena BUMN hanya memberikan program pelatihan 22,22\% UKM, dan tidak memberikan program 
pendidikan maupun pemagangan seperti yang diatur pada Peraturan Menteri Negara Badan Usaha Milik Negara Nomor: Per-5/MBU/2007.

3. Pembinaan Usaha tidak terbukti berpengaruh terhadap shareholder value karena minimnya bantuan Pemasaran dan Promosi. Akan tetapi terbukti berpengaruh terhadap human capital yang diperkirakan program pemasaran dan promosi menarik dan memberikan pengetahuan tersendiri bagi SDM.

4. Pengaruh positip dan signifikan Human capital terhadap organizational capital dan firm equity, terjadi bukan karena hasil pembinaan BUMN Mitra, tetapi karena kemampuan internal UKM itu sendiri dalam hal relationship dan manajerial. Demikian juga dengan pengaruh organizational capital terhadap firm equity maupun shareholder value terbukti dan signifikan juga disebabkan karena kemampuan internal UKM yang bersangkutan dalam hal relationship dan manajerial.

5. Firm Equity tidak terbukti berpengaruh positip terhadap Shareholder Value, tetapi justru negatif dengan koefisien parameter sebesar -0,605. Hal ini terjadi karena proses pembelajaran dan proses bisnis tidak berjalan secara maksimal dan cenderung menurun, sehingga menyebabkan peran firm equity juga menurun.

6. Pengaruh simultan terhadap shareholder value, human capital, dan firm equity sangat baik (model fit), kecuali terhadap organizational capital menunjukkan moderat. Model pembinaan yang dilakukan BUMN Mitra tidak sepenuhnya mengikuti Prinsip Paradigma Baru sehingga melemahkan pengaruh pemberian Pinjaman terhadap shareholder value. Sementara itu, Arahan Strategi Pemasaran memperkuat pengaruh Pembinaan Usaha terhadap shareholder value hal mana menunjukkan bahwa arahan strategi pemasaran yang dipilih relevan dengan UKM terkait.

\section{SARAN}

1. Pembinaan SDM harus dilakukan sesuai Peraturan Menteri Badan Usaha Milik Negara Nomor: Per5/MBU/2007. Hasil penelitian menunjukkan bahwa Program Pembinaan yang dilakukan hanya terbatas pelatihan dan sangat minim. Angka menunjukkan hanya $22,22 \%$ UKM yang diikutkan pada Pelatihan.

2. Demikian pula dengan Pembinaan Usaha yang meliputi Bantuan Pemasaran dan Promosi hanya membantu sebanyak 33,33\% UKM.

3. Kementerian BUMN perlu membuat kebijakan reward and punishment untuk mendorong agar BUMN memiliki motivasi yang kuat dalam melakukan kemitraan dengan UMKM. Terlebih nilai plus bagi BUMN yang dapat bermitra dengan UKM yang inline dengan core bisnis dari BUMN yang bersangkutan.

4. Bagi peneliti lain, dapat mengembangkan penelitian ini untuk cakupan wilayah yang lebih luas seperti tingkat provinsi sehingga lebih merepresentasikan bagaimana Program Kemitraan tersebut dilaksanakan oleh pemerintah melalui BUMN.

\section{DAFTAR PUSTAKA}

Brigham dan Houston. Fundamentals Of Financial Management (Terjemahan). Jakarta: Salemba Empat, 2006.

Dessler, Gary. Human Resources Management, International Tenth Edition. Prentice Hall Inc, 2005. 
Dipta, I Wayan. Strategi Penguatan Usaha Mikro, Kecil dan Menengah (UMKM) melalui kerjasama Kemitraan Pola CSR. Infokop Volume 16, September Tahun 2008.

Dipta, I. Wayan. http://www.smecda.com/deputi7/file_ma kalah/era-perekonomian-baru.pdf

Ghozali, Imam. Structural Equation Modeling, Metode Alternatif dengan Partial Least Square, PLS. Edisi 2. Semarang: Badan Penerbit Universitas Diponegoro, 2008.

Gomes, Faustino Cardoso, Manajemen Sumber Daya Manusia. Yogyakarta: Andi Offset, 2003

http://miswans.com/kiat-mengikuti-pameranbagi-ukm.php, 18 Desember 2010.

Jogiyanto. Metodologi Penelitian Bisnis: Salah Kaprah dan PengalamanPengalaman. Yogyakarta: BPFE, 2007.

Kaplan, Robert S. dan David P. Norton. The Strategy-Focused Organization: How Balanced Scorecard Companies Thrive in The New Business Environment. Boston: Harvard Business School Press, 2001.

Kotler, Philip dan Armstrong, Gary. Principles of Marketing. New Yersey: Prentice-Hall Inc, 1989

Mulyadi. Balanced Scorecard: Alat Manajemen Kontemporer Untuk Melipatganda Kinerja Keuangan Perusahaan. Jakarta: Salemba Empat, 2001.
Peraturan Menteri BUMN No. Per05/MBU/2007 tentang Program Kemitraan Badan Usaha Milik Negara dengan Usaha Kecil Dan Program Bina Lingkungan.

Riyanto, Bambang. Dasar Dasar Pembelanjaan Perusahaan. Yogyakarta:BPFE, 2008.

Sinaga. Balanced Scorecard sebagai pengukuran kinerja koperasi dan UKM, apa mungkin?. Infokop Nomor 25 Tahun XX, 2004.

Soeprihanto, John. Penilaian Kinerja dan Pengembangan Karyawan, Edisi Pertama. Yogyakarta: BPFE, 1998.

Sugiyono. Metode Penelitian Bisnis. Bandung: Alfabeta, 2008

Tamba, Halomoan. Mencari Format Kebijakan Pemasaran UKM. Infokop Nomor 25 Tahun XX, 2004.

Teguh, Muhammad. Metodologi Penelitian Ekonomi, Teori dan Aplikasi. Jakarta: PT. Raja Grafindo Persada, 2001.

UU No 19 Tahun 2003 tentang Badan Usaha Milik Negara.

UU No 20 Tahun 2008 tentang UMKM

Wiyono, Gendro. Merancang Penelitian Bisnis Dengan Alat Analisis SPSS 17.0 \& SmartPLS 2.0. MM-UST, unpublish. 2011 